\title{
Introduction: enacting modernity in the Pacific?
}

\author{
GEORGE N. CURRY, GINA KOCZBERSKI \& JOHN CONNELL, \\ Curtin University, Australia; Curtin University, Australia; University of Sydney, \\ Australia
}

The reference for this article is:

Curry, G.N., Koczberski, G. and Connell, J. (2012). Introduction: enacting modernity in the Pacific? Australian Geographer 43(2), 115-125.

Please note that there may be some minor differences between this PDF version of the paper and the published article. Reprints of this article can be obtained from George Curry $<$ g.curry"at"curtin.edu.au $>$

Rural and urban communities in the culturally and economically diverse Pacific region are experiencing significant economic, environmental and social change as they grapple with the challenges and opportunities of globalisation, modernity and environmental change. Earlier views of an inevitable and linear transformation of indigenous societies as they became incorporated through globalisation of economies, societies and cultures are now giving way to more nuanced understandings of the complexities of change and the importance of local agency in shaping the direction and pace of change. With greater attention to local-level factors and the role of agency, the notion of pre-determined outcomes is being questioned by the recognition that change is neither unidirectional nor, indeed, a scripted transition from a pre-capitalist economy to a capitalist one or from tradition to modernity; rather, the outcome is messier and the indeterminacy of the encounter with various notions of capitalism means that a diversity of local outcomes is to be expected.

A challenge is how to conceptualise and understand these processes at various scales, and the relationships across scales, and in quite different places. The geographer's task, then, is to disentangle these multiple processes and logics to understand how these diverse modernities are created and what they mean for, and how they are valued by, local communities experiencing and contributing to these changes. The papers in this issue, which emerged mainly from a special session on 'Migration, Land and Livelihoods' at the 2009 annual IAG conference, all adopt a local-level approach to explore processes of change in some of the countries to Australia's north, although all are cognisant of macro-level processes and how they interact with local-level factors to shape social and economic outcomes at the local level. Whilst migration and access to land are common threads to this collection, the papers make a broader contribution to ideas and concepts in development, particularly to recent ideas on the enduring influence of indigenous economic and social forms and their role in creating alternative modernities.

\section{Land}

Land in most agriculturally-based Pacific societies is more than an economic asset. Land holds a prominent position in providing sustenance, cultural and spiritual beliefs, in social and ritual activities, social organisation and in creating an individual and group's sense of social identity and belonging. Eighty years ago on the east coast of New Caledonia, the distinguished ethnographer/missionary Leenhardt noted that society was 'written on the ground'. Melanesians were so closely tied to their land that it defined who they were - land was crucial to the past, essential for the present and critical for the future. Membership in landholding groups not only continues to provide access to land but it also defines who people are, while ties between land and identity forge an eternal bond of belonging to place. Land was associated with the ancestors, and 'rocks, plants and the human body originate in 
similar structures' (Leenhardt 1947/79, p. 61), and place, language and time were tied together. Indeed, the past may be understood spatially as much as temporally (Kahn 2011). As Sillitoe points out for the Wola of the Highlands of Papua New Guinea (PNG):

In a sense Wola belong to the land as much as it belongs to them ... They have a deep affection for their land, talk warmly about it - how their father or ancestor cultivated where they currently have gardens and relate events witnessed in the vicinity, such as battles, ceremonies and so on. Land has an everlasting aspect; it is their connection with the past and the future ... All kin, including dead ancestors and unborn descendants, depend on the same land. (Sillitoe 1999, pp. 348-9)

This intense attachment to land and its centrality to social identity underpins the widely held view amongst customary landowners that land is inalienable. Even at massively transformed mine sites landowners rarely migrate away from the project and its disturbances. To be landless is an unimaginable and inconceivable misfortune. All of this helps to explain why in many areas of the Pacific the notion that land can be alienated permanently is unacceptable to customary landowners and is the root cause of much conflict across the island arc from Timor eastwards through the Pacific Islands.

\section{Post-contact}

Despite the centrality of land in culture and society, customary land tenures are also dynamic and have been modified considerably in response to changing circumstances and new opportunities associated with colonialism, capitalism and the emergence of market economies (Crocombe 1971; Ward 1995; Ward \& Kingdon 1995; Strathern \& Stewart 1998; Martin 2007). Whilst large tracts of customary land were alienated - mainly for plantations in the pre-independence period - much has remained under customary ownership or has been returned to customary ownership since independence. However, land has increasingly been placed under new stresses as a result of population pressures and new demands on land for development. As the papers in this collection reveal, three key drivers of change include large-scale resource development pressures (mining, logging and commodity crop production), urbanisation and internal migration, while environmental hazards have also precipitated and necessitated new approaches to land tenure.

Across the region land tenure is being modified at a range of scales from the 'land-grabbing' efforts of mainly international companies seeking access to large tracts of land, often for logging, mining and commercial crop production but also for urbanisation, or even tourism (Filer 2011; Slatter 2006). Areas of large-scale commodity crop production and mine sites are becoming hotspots for conflict as these projects of modernity and development are associated with significant inmigration from poor, peripheral regions, thereby placing additional demands on customary land. The scale and nature of this in-migration often irreversibly restructures local relationships so that local communities may feel dispossessed, marginalised or displaced not just from the project but also from the sheer number of people arriving on their lands (Banks 2009; Bainton 2010).

Throughout the Pacific, people are leading increasingly mobile lives as they seek new livelihood opportunities. Whilst much of this migration is rural-to-urban, a sizeable proportion is rural-to-rural, particularly to agricultural and resource frontier zones where communal tenure is the dominant form of land tenure. In pursuit of livelihoods, land-poor migrants are entering into a broad range of formal and informal arrangements with customary 
landowners to gain short- and long-term access to land, thereby creating burgeoning informal land markets and changes to customary land tenure regimes. These movements, some of which are now multi-generational, mean that village communities are becoming more dispersed, leadership more fragmented, and 'real' landowners multiplying as marriage networks widen spatially and culturally and migrants make claims on the land of their hosts. People's intimate attachments to land are therefore weakening, allowing land to be viewed more as a commodity. As none other than Francis Fukuyama has pointed out,

The fact that there are multiple classes of claimants to a particular parcel of land, no strong tradition of delegated authority, and no statute of limitations with regard to customary claims, means that it is extremely difficult ... to come up with schemes by which landowners can pool resources to convert customary land into modern alienable property. (2008, p. 21)

But that supposes that landowners wish to be entirely engaged in the capitalist system. In most cases they do not. The production of commodity crops not only places more pressure on land by removing land from subsistence production, thereby intensifying pressure on the subsistence base, but also requires significant changes to land tenure as land is converted from annual cropping over a few seasons to perennial export cash cropping. As more land is devoted to commercial agriculture and comes under semi-permanent commercial production, usufruct rights remain vested in the same families or individuals for very long periods. This long-term alienation of land for commercial purposes is leading people to claim exclusive rights of access to, and inheritance of, these resources. The outcome is that communal tenure is giving way to individual tenure with a consequent loss of flexibility in the allocation of land rights. However, as detailed studies have increasingly shown, awareness of the problems attached to the loss of flexibility has discouraged landowners from moving in that direction, even where pressures in the vicinities of mines would seem to offer tremendous opportunities for landowners to capitalise on economic rents.

\section{Traditional land tenure can accommodate change}

Whilst migration has been a focus of research amongst geographers, less attention has been paid to understanding the local-level processes and mechanisms by which migrants without land use rights gain access to customary land and other resources to construct livelihoods in their new homes. Although the flexibility and adaptability of customary land tenure practices in PNG and the Pacific that enabled 'outsiders' to cultivate temporary food gardens on another's customary land has been noted (e.g. Crocombe \& Hide 1971; Jorgensen 2007), the gifting or 'selling' of land for the cultivation of perennial export tree crops or for long-term residence was much less common, especially so when the 'outsiders' were from another ethnic group and lacked marital or trading ties with the customary landowning group (Curry 1997). Thus recent changes associated with resource developments where large numbers of migrants are settling and gaining relatively long-term access to land - over several generations in some cases - is leading to complex land tenure arrangements. These transactions involve difficult choices for both migrants and landowners, as reflected in this set of papers. At mine sites particularly this has led to rapidly evolving and complex contexts where the claims of multiple landowners challenge the abilities of local and national governments and mining companies to regulate or cope with the speed of change and the diversity of claims. Legal recognition of the complex variety of customary forms of landownership has ensured that companies operating in the Pacific are drawn into intense and often continuing engagement with local landowning groups over compensation, royalty 
payments, the services and employment that mines particularly deliver and their environmental and social impacts. Indeed, the relationships between land, people and mine sites have extended the issues that surround the limits and boundaries of corporate social responsibility (Banks 2006). In 1988 the Bougainville copper mine in PNG closed down after unresolved tension over such issues spilled over into sustained violence (Filer 1990; Connell 1991).1 The papers explore gradual or evolutionary processes of change as well as rapid and sometimes conflicted change*urbanisation (Numbasa \& Koczberski this issue), rural-to-rural migration (Allen this issue; Koczberski et al. this issue), and the migration of whole groups from hazardous environments (Connell this issue); and, in East Timor, the legacy of late colonial pressure with forced resettlement (Thu this issue). Sometimes these new land tenure arrangements entail the superimposition of alien ideologies and practices which are usually in some way superficial, while others such as Western models of land tenure promoted by national governments, aid organisations and consultants remain 'foreign flowers' (Larmour 2005) that never do fit.

What is clear from the papers in this issue is that for most customary landowners, land rights granted to private companies, migrants or the state are rarely seen as permanent and exclusive. Customary landowners' ongoing sense of 'ownership' of their 'alienated' land adds a layer of uncertainty to land transactions. Notions of partial alienation of customary land raise new questions of equity and uneven development and the nature of identity, tied as it is to land, for both landowners and migrants (Koczberski \& Curry 2004; Allen this issue). These issues become even more complicated by the sudden arrival of migrants after hazard events (Connell this issue), or the short-term nature of many mining operations, which can induce landowners to appropriate mining benefits disproportionally, thereby marginalising migrants (Banks 2008).

\section{Embedded in social relationships}

The papers in this issue fit into a growing body of literature from the Pacific region that shows how indigenous economic logics shape contemporary economic practices and values in such a way as to reconfigure people's relationship with global capitalism to give it cultural meaning (Gregory 1982; LiPuma 1999, 2000; Curry 2003; Jolly 2005; Sahlins 2005; Connell 2007a, b; Cahn 2008; Curnow 2008; McGregor 2009; Thornton et al. 2010; Patterson \& Macintyre 2011; Curry \& Koczberski 2012). Each case study highlights how customary land tenure regimes and other established social structures have a capacity to accommodate change while remaining grounded in local social and cultural institutions, making generalisations difficult (e.g. Curry 2003; McDougall 2005; Connell 2007b; Curry \& Koczberski 2009). Many Pacific people have sought to combine a greater degree of cultural continuity with the impossibility of denying the necessity for economic development and so retreating from modernity. Excursions into capitalism, in whatever variant, have therefore increasingly been seen as cautious essays in economic hybridity that did not, however, contest or reject the renewed expansion of capitalism (Gegeo 1998; Yang 2000; Connell 2007a) but simply sought more successful and more culturally sensitive forms of accommodation to it. At every site of change, complex, culturally encoded changes are played out. Terms such as entanglement, hybridisation, syncretism, multiple modernities, alternative modernities, and cultural appropriation have been used to refer to this complex weaving together of old and new, tradition and modernity, indigenous and foreign and nonmarket and market (LiPuma 2000; Evans 2001; Horan 2002; James 2002; Curry 2003; Wardlow 2006; Curry \& Koczberski 2009; Besnier 2011). As Sahlins (2000, p. 9) notes: 'in 
all change there is continuity' and the outcome is a diverse array of distinctively different place-based economic and social forms.

This process of hybridisation or blending of indigenous and introduced forms of economy and social values can be thought of, in a Polanyian sense, as the embedding in social relationships of introduced economic forms and values (Polanyi 1944; Polanyi et al. 1957; see Curry \& Koczberski 2012 for a fuller discussion). Whilst land transactions seemingly entail the commodification of land, access rights are gained through people negotiating socioeconomic and political relations that are grounded in place-based social practices and values that draw on an indigenous morality and non-market relationships. In negotiations with customary landowners for access to land, 'outsiders', whether companies or migrants, must often straddle both the market economy and the indigenous nonmarket economy to first initiate and then maintain relationships with their 'host' landowners (Allen this issue; Koczberski et al. this issue; Numbasa \& Koczberski this issue; Thu this issue). By embedding land use rights and practices in social relationships with customary landowners, outsiders are able to legitimise their land claims through an indigenous morality that allows them longterm access rights to the land of their hosts. As social networks evolve outsiders may be recategorised from strangers, even enemies, to guests. Yet, despite the diverse social relationships migrants pursue to gain access rights, there remains a great deal of fluidity and uncertainty in these relational economies of land, and in most contexts, whether at mine sites, settlement schemes or in urban centres, migrants invariably remain vulnerable to the decisions and actions of landowners.

The persistence in modified form of relational economies of land tenure in capital-intensive mining and plantation zones may seem paradoxical. As discussed above, these new forms of tenure arrangements do not involve the displacement of indigenous land tenure by Western land tenure systems, despite sustained efforts by colonial powers and by major multilateral organisations since then, and nor are they simply reproducing traditional forms. Rather, they involve a reworking of customary land tenure which, while still compatible with longstanding principles of indigenous land tenure, has clearly been modified to meet the new requirements of the cash economy and resource development needs. By acknowledging the role of social relationships in accessing resources, the papers in this issue bring a different perspective to the study of global and local interactions by according greater recognition to the role of place-based, local-level factors in shaping trajectories of change and the governance of resource rights.

What is also clear from this set of papers is the capacity of customary landowners and outsiders - companies and migrants - to develop new forms of tenure systems that are able to move beyond the limitations of the state in land matters. In many ways, the state lags behind what is happening on the ground. In PNG, for instance, the weak and diminishing authority of the state in land matters and the growing assertiveness of landowners in their relationships with the state and capital is illustrated by the rising numbers of compensation claims and other landowner demands on government and developers, and the strong bargaining position of landowning groups in resource development negotiations on their land (Filer 1997;

Standish 2001; Banks 2008; Bainton 2009). As these papers show, there is much pressure on land in resource development sites, and in the absence of effective state management of land transactions people on the ground negotiate their own ways of resolving these issues as best they can.

\section{Policy implications}


The papers in this issue illustrate the rising development pressures on customary land, the emergence of tensions and social conflict between customary landowners and migrants associated with growing levels of mobility characterising contemporary life in the region. Within this changing social and economic milieu, land has become a major planning problem for urban development, mining and agricultural development. For many external observers the complexities of customary land tenure are a major brake on development and a substantial constraint on leasing or selling land and thus establishing a viable private sector necessary for economic development (Gosarevski et al. 2004). Many countries have consequently attempted to pursue land reform programs to convert customary land to individual property rights in the form of freehold or individual leasehold title. Yet in societies where land is much more than an economic asset - where society is 'written on the ground' - land ownership is complex and not easily amenable to translation into Western codes and conventions. In Ranongga, Solomon Islands, for example, for 50 years outside agencies have consistently called for the clarification of property rights as the necessary starting point for any form of modern economic development. Local residents are eager to have their rights recognised by outsiders and by other islanders, but transforming complex, cross-cutting localised relationships into abstract rights that are commensurable, predictable and knowable to outsiders raises major political and ethical dilemmas for Ranongga leaders. Claiming exclusive rights to land for oneself or one's group would negate long-standing elements of reciprocity and the relative ease of incorporation of outsiders, and would effectively alienate those others who are essential for the proper functioning of the local polity. Westernisation of land tenure thus threatens the tenuous achievement of unity that Ranonggans see as the prerequisite to peace, prosperity and, as they understand it, proper development (McDougall 2005). In other words, there are real advantages for local development when land tenure remains flexible and even subject to competing claims rather than being finalised and fossilised through the imposition of Western models of individual and alienable land rights so as to become a source of overt contention.

As the papers in this issue show, landowners are not seeking a radical change to customary tenure principles to enable them to free up their land for development projects or to capitalise on the income opportunities of migrants' demand for land. Landowners want to retain 'ownership' and control of their land and wish to see migrants' access rights socially embedded within a relational economy (e.g. sharing of wealth and maintaining indigenous exchange relationships). Acknowledging such sentiments and values is critical for developing culturally appropriate policies to mobilise customary land for development. Moreover, given the failure of land tenure reform that sought to impose Western notions of land tenure (individual and alienable rights), it is now recognised that adaptation, not replacement, of customary tenures is the most appropriate way to resolve land issues for future developments (Fingleton 2005; Koczberski et al. this issue). New local land usage agreements can be developed that draw on customary principles of land tenure - the relational dimensions of the economy - while providing improved tenure security for migrants cultivating cash crops. These new agreements address the need for a relational dimension to land transactions which gives them greater validity in the eyes of customary landowners than previous attempts to commodify land transactions which inevitably led to conflicts and sometimes the eviction of settlers (see also Curry \& Koczberski 2009; Koczberski et al. 2009). However, a significant task in many places is for land tenure agreements to become flexible enough to enable and accommodate the settlement of those displaced through no fault of their own, or those who have migrated to urban areas, where land is particularly scarce and deeply contested. Indeed, particular challenges in rapidly growing capital cities have meant complex and diverse processes over many decades to resolve land tenure (e.g. Goddard 2010; Connell 2011) but 
which often stubbornly remain unresolved. It is here that the tensions of modernity are greatest.

\section{Concluding comments}

The papers in this collection deal with what could be labelled frontier zones where global capital in the form of mining, plantation development and associated programs of resettlement interact with local societies, cultures and economies. In this encounter, customary landowners strive to maintain an indigenous, though certainly modified, system of land tenure and economy that remains grounded in place-based social practices and values imbued with an indigenous morality. What the papers show is that these new forms of tenure arrangements and socio-economic relationships with outsiders have not involved the transformation (or destruction) of indigenous forms of land tenure and social organisation grounded in relational identities, and nor are they locked in an unchanging tradition. Instead, they reflect a fair degree of agency whereby local place-based practices embedded in indigenous social and cultural frameworks are constantly being reworked in the interaction with macro-level processes to create a range of alternative modernities.

The creation of alternative modernities through the inflection of development highlights how at the local level people strive to maintain their identity in the context of change, and desire to forge a modernity compatible with their own registers of value. Modernity embraces both opportunities to escape the constraints of kin and community and desires to 'remake and reawaken the autonomy of that community' (LiPuma 2000, p. 10). An emphasis on locality and on globalisation did not bind together antithetical phenomena. Interplay between the local and the global is at the heart of the battle for a compatible modernity, and the desire to determine destiny. Moreover, an insistence on hybridity, evident in the case studies both here and elsewhere, is not only significant within the relatively small-scale communities discussed here but is central to much wider ongoing state building in what remain relatively new nations (Brown \& Gusmao 2009; Richmond 2011). In this way, much of what is valued in local life remains: a sense of community in association with a particular tract of land; shared beliefs and values; a rough equality of material conditions; reciprocity and some degree of community control over the means of production. Such values and virtues have enabled localised forms of autonomy and self-reliance that are not readily transferable into a more globalised world (McDougall 2005), just as many Western values and institutions remain fragile 'foreign flowers' (Larmour 2005).

Whilst globalisation and modernity have resulted in considerable social and economic change, there remain significant elements of continuity as people have seized opportunities to expand their participation in development while at the same time striving to maintain placebased cultural beliefs, ideologies and moral domains that shape everyday decisions and practices, whether they be landowners or poor rural migrants seeking a better life. Yet, in a region where cultures remain vibrant what has become now almost a familiar cultural turn in other parts of the world (Schech \& Haggis 2000; Radcliffe 2005, 2006) can still be remarkably absent. While Radcliffe and Laurie argue that 'increasingly development looks to culture as resource and as a significant variable explaining the success of development interventions' (2006, p. 231), within the island Pacific there is little sign that culture, in whatever form, is seen as a resource but much more that it is seen as a brake on hopeful structures of development. However, as evidenced by the papers in this issue, and elsewhere, culture needs to be viewed not as a threat to development but as a core element. 


\section{NOTE}

1. This special issue was intended to include a valuable paper on the relationships between migrants, landowners, governments and the company at one particular Pacific mine site, which would not only have given a better balance to the collection but emphasised the challenges to policy formation in rapidly changing circumstances. Unfortunately at the very last minute the paper was withdrawn because the mining company involved perceived these relationships to be too sensitive to be even reported and sensibly discussed. While the editors of this issue and the author of the paper regard it as a classic form of corporate myopia and paranoia it well reflects the acute sensitivities, frictions and tensions that mark sites of rapid change.

\section{REFERENCES}

BAINTON, N. (2009) 'Keeping the network out of view: mining, distinctions and exclusion in Melanesia', Oceania 79(1), pp. 18-33.

BAINTON, N. (2010) The Lihir destiny: cultural responses to mining in Melanesia, ANU E Press, Canberra.

BANKS, G. (2006) 'Mining, social change and corporate social responsibility: drawing lines in the Papua New Guinea mud', in Firth, S. (ed.) Globalisation and governance in the Pacific Islands, ANU E Press, Canberra, pp. 259-74.

BANKS, G. (2008) 'Understanding 'resource'” conflicts in Papua New Guinea', Asia Pacific Viewpoint 49(1), pp. 23-4.

BANKS, G. (2009) 'Activities of TNCs in extractive industries in Asia and the Pacific: implications for development', Transnational Corporations 18(1), pp. 43-60.

BESNIER, N. (2011) On the edge of the global: modern anxieties in a Pacific Island nation, Stanford University Press, Stanford.

BROWN, A. \& GUSMAO, A. (2009) 'Peacebuilding and political hybridity in East Timor', Peace Review 21(1), pp. 61-9.

CAHN, M. (2008) 'Indigenous entrepreneurship, culture and micro-enterprise in the Pacific Islands: case studies from Samoa', Entrepreneurship and Regional Development 20(1), pp. 1-18.

CONNELL, J. (1991) 'Compensation and conflict: the Bougainville Copper Mine, Papua New Guinea', in Connell, J. \& Howitt, R. (eds) Mining and Indigenous peoples in Australasia, Sydney University Press, Sydney, pp. 55-76.

CONNELL, J. (2007a) 'Holding on to modernity? Siwai, Bougainville, Papua New Guinea', in Connell, J. \& Waddell, E. (eds) Environment, development and change in Rural Asia-Pacific, Routledge, London, pp. 127-46.

CONNELL, J. (2007b) 'Islands, idylls and the detours of development', Singapore Journal of Tropical Geography 28(2), pp. 116-35.

CONNELL, J. (2011) 'Elephants in the Pacific? Pacific urbanisation and its discontents', Asia Pacific Viewpoint 52(2), pp. 121-35.

CROCOMBE, R. (ed.) (1971) Land tenure in the Pacific, Oxford University Press, Melbourne.

CROCOMBE, R. \& HIDE, R. (1971) 'New Guinea: unity in diversity', in Crocombe, R. (ed.) Land tenure in the Pacific, Oxford University Press, Melbourne, pp. 292-333.

CURNOW, J. (2008) 'Making a living on Flores, Indonesia: why understanding surplus distribution is crucial to economic development', Asia Pacific Viewpoint 49(3), pp. 370-80.

CURRY, G.N. (1997) 'Warfare, social organisation and resource access amongst the Wosera Abelam of Papua New Guinea', Oceania 67(3), pp. 194-217. 
CURRY, G.N. (2003) 'Moving beyond postdevelopment: facilitating indigenous alternatives for "development", Economic Geography 79, pp. 405-23.

CURRY, G.N. \& KOCZBERSKI, G. (2009) 'Finding common ground: relational concepts of land tenure and economy in the oil palm frontier of Papua New Guinea', Geographical Journal 175(2), pp. 98-111.

CURRY, G.N. \& KOCZBERSKI, G. (2012) 'Relational economies, social embeddedness and valuing labour in agrarian change: an example from the developing world', Geographical Research doi: 10.1111/j.1745-5871.2011.00733.x

EVANS, M. (2001) Persistence of the gift: Tongan tradition in transnational context, Wilfred Laurier University Press, Waterloo.

FILER, C. (1990) The Bougainville rebellion, the mining industry and the process of social disintegration in Papua New Guinea, Canberra Anthropology 13(1), pp. 1-39.

FILER, C. (1997) 'Compensation, rent and power in Papua New Guinea', in Toft, S. (ed.) Compensation for resource development in Papua New Guinea, Law Reform Commission of Papua New Guinea and Resource Management in Asia and the Pacific, Research School of Pacific and Asian Studies, Australian National University, Canberra, pp. 156-90.

FILER, C. (2011) The new land grab in Papua New Guinea, ANU State Society and Governance Discussion Paper 2011/2, Canberra.

FINGLETON, J. (2005) 'Conclusion', in Fingleton, J. (ed.) Privatising land in the Pacific: a defence of customary tenures, Discussion Paper No. 80, Australia Institute, Canberra, pp. 34-7.

FUKUYAMA, F. (2008) 'State building in Solomon Islands', Pacific Economic Bulletin 23(3), pp. 18-34.

GEGEO, D. (1998) 'Indigenous knowledge and empowerment: rural development examined from within', The Contemporary Pacific 10(2), pp. 289-316.

GODDARD, M. (2010) 'Heat and history: Moresby and the Motu-Koita', in Goddard, M. (ed.) Villagers and the city: Melanesian experiences of Port Moresby, Papua New Guinea, Sean Kingston, Wantage, pp. 19-46.

GOSAREVSKI, S., HUGHES, H. \& WINDYBANK, S. (2004) 'Is Papua New Guinea viable with customary land ownership?', Pacific Economic Bulletin 19(3), pp. 133-6.

GREGORY, C.A. (1982) Gifts and commodities, Academic Press, New York and London.

HORAN, J.C. (2002) 'Indigenous wealth and development: micro-credit schemes in Tonga', Asia Pacific Viewpoint 43(2), pp. 205-21.

JAMES, K.E. (2002) 'Disentangling the "'grass roots" in Tonga: "traditional enterprise", and autonomy in the moral and market economy', Asia Pacific Viewpoint 43(3), pp. 269-92.

JOLLY, M. (2005) 'Beyond the horizon? Nationalisms, feminisms, and globalisation in the Pacific', Ethnohistory 52(1), pp. 137-66.

JORGENSEN, D. (2007) 'Changing minds: hysteria and the history of spirit mediumship in Telefolmin', in Barker, J. (ed.) The anthropology of morality in Melanesia and beyond, Ashgate, Aldershot, pp. 113-30.

KAHN, M. (2011) Tahiti beyond the postcard: power, place and everyday life, University of Washington Press, Seattle.

KOCZBERSKI, G. \& CURRY, G.N. (2004) 'Divided communities and contested landscapes: mobility, development and shifting identities in migrant destination sites in Papua New Guinea', Asia Pacific Viewpoint 45(3), pp. 357-73.

KOCZBERSKI, G., CURRY, G.N. \& IMBUN, B. (2009) 'Property rights for social inclusion: migrant strategies for securing land and livelihoods in Papua New Guinea', Asia Pacific Viewpoint 50(1), pp. 29-42. 
LARMOUR, P. (2005) Foreign flowers, institutional transfer and good governance in the Pacific Islands, University of Hawai'i Press, Honolulu.

LEENHARDT, M. (1947/79) Do Kamo: person and myth in the Melanesian World, University of Chicago Press, Chicago (Gallimard, Paris, 1947).

LIPUMA, E. (1999) 'The meaning of money in the age of modernity', in Akin, D. \& Robbins, J. (eds) Money and modernity: state and local currencies in Melanesia, University of Pittsburgh Press, Pittsburgh, pp. 192-231.

LIPUMA, E. (2000) Encompassing others: the magic of modernity in Melanesia, University of Michigan Press, Ann Arbor.

MARTIN, K. (2007) 'Land, customary and non-customary, in East New Britain', in Weiner, J.F. \& Glaskin, K. (eds) Customary land tenure and registration in Australia and Papua New Guinea: anthropological perspectives, Asia-Pacific Environment Monograph 3, ANU E Press, Canberra, pp. 39-56.

MCDOUGALL, D. (2005) 'The unintended consequences of clarification: development, disputing, and the dynamics of community in Ranongga, Solomon Islands', Ethnohistory 52(1), pp. 81-109.

MCGREGOR, A. (2009) 'New possibilities? Shifts in post-development theory and practice', Geography Compass 3, pp. 1688-702.

PATTERSON, M. \& MACINTYRE, M. (eds) (2011) Managing modernity in the western Pacific, University of Queensland Press, St Lucia.

POLANYI, K. (1944) The great transformation, Rinehart, New York.

POLANYI, K., ARENSBERG, C. \& PEARSON, H. (eds) (1957) Trade and markets in early empires, Glencoe Free Press, New York.

RADCLIFFE, S. (2005) 'Development and geography: towards a postcolonial development geography?', Progress in Human Geography 29(3), pp. 291-8.

RADCLIFFE, S. (2006) 'Culture in development thinking: geographies, actors and paradigms', in Radcliffe, S. (ed.) Culture and development in a globalizing world, Routledge, London, pp. 1-29.

RADCLIFFE, S. \& LAURIE, N. (2006) 'Culture and development: taking culture seriously in development for Andean indigenous people', Environment and Planning D: Society and Space 24(2), pp. 231-48.

RICHMOND, O. (2011) 'De-romanticising the local, de-mystifying the international: hybridity in Timor Leste and the Solomon Islands', The Pacific Review 24(1), pp. 11536.

SAHLINS, M. (2000) Culture in practice: selected essays, Zone Books, New York.

SAHLINS, M. (2005) 'The economics of develop-man in the Pacific', in Robbins, J. \& Wardlow, H. (eds) The making of global and local modernities in Melanesia: humiliation, transformation and the nature of cultural change, Ashgate, Farnham, pp. 23-43.

SCHECH, S. \& HAGGIS, J. (2000) Culture and development: a critical introduction, Blackwell, Oxford.

SILLITOE, P. (1999) 'Beating the boundaries: land tenure and identity in the Highlands of Papua New Guinea', Journal of Anthropological Research 55(3), pp. 331-60.

SLATTER, C. (2006) The Con/Dominion of Vanuatu? Paying the price of investment and land liberalisation - a case study of Vanuatu's tourism industry, Oxfam New Zealand, Auckland.

STANDISH, B. (2001) 'Papua New Guinea in 1999-2000', Journal of Pacific History 36(3), pp. 285-98.

STRATHERN, A. \& STEWART, P. (1998) 'Shifting places, contested spaces: land and identity politics in the Pacific', Australian Journal of Anthropology 9(2), pp. 209-24. 
THORNTON, A., KERSLAKE, M.T. \& BINNS, T. (2010) 'Alienation and obligation: religion and social change in Samoa', Asia Pacific Viewpoint 51(1), pp. 1-16.

WARD, R.G. (1995) 'Land, law and custom: diverging realities in Fiji', in Ward, R.G. \& Kingdon, E. (eds) Land, custom and practice in the South Pacific, Cambridge University Press, Cambridge, pp. 198-249.

WARD, R.G. \& KINGDON, E. (eds) (1995) Land, custom and practice in the South Pacific, Cambridge Asia-Pacific Studies, Cambridge University Press, Cambridge.

WARDLOW, H. (2006) Sexuality and agency in a New Guinea society: wayward women, University of California Press, Berkeley.

YANG, M.M. (2000) 'Putting global capitalism in its place: economic hybridity, Bataille and ritual expenditure', Current Anthropology 41(4), pp. 477-510. 